Marquette University

e-Publications@Marquette

$4-2012$

\title{
Synthesis and Structural Characterization of Iron(II) Complexes with Tris(imidazolyl)phosphane Ligands: A Platform for Modeling the 3-Histidine Facial Triad of Nonheme Iron Dioxygenases
}

Michael M. Bittner

Marquette University, michael.bittner@marquette.edu

Jacob Baus

Marquette University, jacob.baus@marquette.edu

Sergey V. Lindeman

Marquette University, sergey.lindeman@marquette.edu

Adam T. Fiedler

Marquette University, adam.fiedler@marquette.edu

Follow this and additional works at: https://epublications.marquette.edu/chem_fac

Part of the Chemistry Commons

\section{Recommended Citation}

Bittner, Michael M.; Baus, Jacob; Lindeman, Sergey V.; and Fiedler, Adam T., "Synthesis and Structural Characterization of Iron(II) Complexes with Tris(imidazolyl)phosphane Ligands: A Platform for Modeling the 3-Histidine Facial Triad of Nonheme Iron Dioxygenases" (2012). Chemistry Faculty Research and Publications. 574.

https://epublications.marquette.edu/chem_fac/574 
Marquette University

e-Publications@Marquette

Chemistry Faculty Research and Publications/College of Arts and Sciences

This paper is NOT THE PUBLISHED VERSION.

Access the published version at the link in the citation below.

European Journal of Inorganic Chemistry, Vol. 2012, No. 11 (April 2012): 1848-1856. DOI. This article is (C) Wiley and permission has been granted for this version to appear in e-Publications@Marquette. Wiley does not grant permission for this article to be further copied/distributed or hosted elsewhere without the express permission from Wiley.

\section{Synthesis and Structural Characterization of Iron(II) Complexes with Tris(imidazolyl)phosphane Ligands: A Platform for Modeling the 3-Histidine Facial Triad of Nonheme Iron Dioxygenases}

Michael M. Bittner

Department of Chemistry, Marquette University, Milwaukee, WI Jacob S. Baus Department of Chemistry, Marquette University, Milwaukee, WI Sergey V. Lindeman Department of Chemistry, Marquette University, Milwaukee, WI Adam T. Fiedler Department of Chemistry, Marquette University, Milwaukee, WI 


\section{Abstract}

Several monoiron(II) complexes containing tris(imidazolyl)phosphane (TIP) ligands have been prepared and structurally characterized by using X-ray crystallography and NMR spectroscopy. Two TIP ligands were employed: tris(2-phenylimidazol-4-yl)phosphane (4-TIPPh) and tris(4,5-diphenyl-1-methylimidazol2-yl)phosphane (2-TIP Ph2). These tridentate ligands resemble the 3-histidine (3His) facial triad found recently in the active sites of certain nonheme iron dioxygenases. Three of the reported complexes are designed to serve as convenient precursors to species that model the enzyme-substrate intermediates of $3 \mathrm{His}$ dioxygenases; thus, each contains an $\left[\mathrm{Fe}\left(\mathrm{k}^{3}-\mathrm{TIP}\right)\right]^{2+}$ unit in which the remaining coordination sites are occupied by easily displaced ligands, such as solvent molecules and/or carboxylate groups. The viability of these complexes as precursors was demonstrated through the synthesis of TIP-based complexes with $\beta$-diketonate and salicylate ligands that represent faithful models of $\beta$-diketone dioxygenase and salicylate 1,2-dioxygenase, respectively.

\section{Abstract}

A series of monoiron(II) complexes with tris(imidazolyl)phosphane ligands have been generated and characterized by using $X$-ray crystallography. These complexes model the resting and substrate-bound states of certain nonheme iron enzymes, such as $\beta$-diketone dioxygenase and salicylate 1,2dioxygenase, which employ three facially coordinating histidine ligands in their active sites.
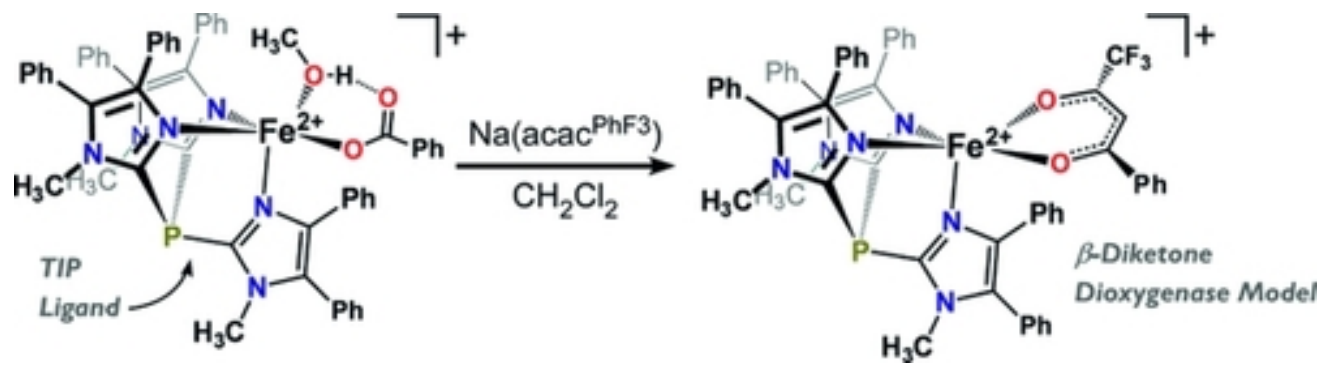

\section{Introduction}

Mononuclear nonheme iron dioxygenases play a central role in the oxidative catabolism of a wide range of biomolecules and pollutants. 1 Members of this enzyme family include the extradiol catechol dioxygenases, $\underline{2}$ Rieske dioxygenases, $\underline{3}$ homogentisate dioxygenase, $\underline{\underline{4}}$ and (chloro)hydroquinone dioxygenases. $\underline{\mathbf{5}}$ These enzymes feature a common active-site motif in which the ferrous center is facially ligated by one aspartate (or glutamate) and two histidine residues [the so-called 2-His-1carboxylate (2H1C) facial triad]. 6 However, recent structural studies have shown that the Asp/Glu ligand in some monoiron dioxygenases is replaced with His, resulting in the 3 His facial triad. 7 Members of this "3His family" catalyze novel transformations that have expanded the known boundaries of Fe dioxygenase chemistry. For example, cysteine dioxygenase (CDO) $\underline{8}$ - the first $3 \mathrm{His}$ enzyme to be structurally characterized - catalyzes the initial step in L-cysteine catabolism by converting the thiol into a sulfinic acid (Scheme 1), while $\beta$-diketone dioxygenase (Dke1) oxidizes acetylacetone to acetic acid and 2-oxopropanal. $\underline{9}$ Other $3 \mathrm{His}$ Fe dioxygenases include gentisate 1,2-dioxygenase (GDO) 10 and salicylate 1,2-dioxygenase (SDO), 11 both of which oxidatively cleave aromatic $\mathrm{C}-\mathrm{C}$ bonds (Scheme $\underline{1}$ ). Each of these microbial enzymes participates in the degradation pathways of polycyclic aromatic hydrocarbons. While the reaction catalyzed by GDO is very similar to those catalyzed by the extradiol 
catechol dioxygenases and likely follows a similar mechanism, SDO is unique in performing the oxidative cleavage of an aromatic ring with only one electron-donating group.

Cysteine Dioxygenase (CDO):<smiles>NC(CS[13CH2][13C](=O)[14C](=O)[O-])C(=O)[O-]</smiles>

$\beta$-Diketone Dioxygenase (Dke1):<smiles>[R]C(=O)C([R])=O</smiles>

Gentisate 1,2-Dioxygenase (GDO):<smiles>C[14CH2][14CH2][14C](=O)/C=C\C(=O)CC(=O)C(=O)O</smiles>

Salicylate 1,2-Dioxygenase (SDO):<smiles>O=C(O)/C=C\C=C/C(=O)C(=O)O</smiles>

\section{Scheme 1}

Our knowledge of nonheme Fe dioxygenases has greatly benefitted from the development of smallmolecule analogues that replicate important structural, spectroscopic, and/or functional properties of the enzyme active sites.12 The $2 \mathrm{H} 1 \mathrm{C}$ triad has been suitably modeled with anionic, tridentate supporting ligands such as tris(pyrazol-1-yl)borates (Tp), 13 bis(pyrazolyl)acetates, 14 and bis(1alkylimidazol-2-yl)propionates.15 The last two ligand sets replicate the mixed $\mathrm{N}_{2} \mathrm{O}$ donor set of the $2 \mathrm{H} 1 \mathrm{C}$ triad by the inclusion of carboxylate arms. Given the unique and significant reactions catalyzed by the 3 His family of Fe dioxygenases, it is important to develop supporting ligands with specific relevance to the $3 \mathrm{His}$ facial triad. To this end, we have sought to exploit the tris(imidazol-2-yl)phosphane (2-TIP ${ }^{\mathrm{R} 2}$ ) and tris(imidazol-4-yl)phosphane (4-TIPR) frameworks shown in Scheme $\underline{2}$, which accurately mimic the charge and donor strength of the $3 \mathrm{His}$ coordination environment. These ligands were initially generated to model the $3 \mathrm{His}$ ligand sets found in the active sites of carbonic anhydrase $\left(\mathrm{Zn}^{2+}\right)$ and cytochrome $c$ oxidase $\left(\mathrm{Cu}^{2+}\right) . \underline{16}$ To date, the application of the TIP framework to Fe systems has been limited to homoleptic $\left[\mathrm{Fe}(\mathrm{TIP})_{2}\right]^{2+/ 3+}$ complexes $\underline{17}$ and carboxylate-bridged diiron(III) species. $\underline{17 \mathrm{c}}, \underline{18}$
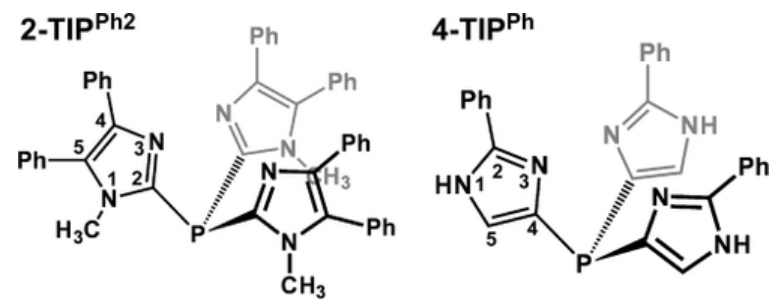

\section{Scheme 2}


A key advantage of the 2-TIPR2 and 4-TIPR ligands is that their steric properties can be easily modified by altering the R substituent(s). Thus far, we have primarily employed the 2-TIPPh2 and 4-TIP Ph ligands, as the steric bulk of the phenyl rings discourages both dimerization and formation of the homoleptic $\left[\mathrm{Fe}(\mathrm{TIP})_{2}\right]^{2+}$ complexes. Recently, we described the synthesis and structural characterization of a series of $\left[\mathrm{Fe}^{2+}\left(4-\mathrm{TIPh}^{\mathrm{Ph}}\right)\left(\operatorname{acac}^{\mathrm{X}}\right)\right]$ OTf complexes $\left(\mathrm{acac}^{\mathrm{X}}=\right.$ substituted $\beta$-diketonate; OTf $=$ triflate) that serve as models of the Dke1 enzyme-substrate complex.19 These models were prepared by directly mixing one equivalent of the sodium salt of the appropriate $\beta$-diketone, $\mathrm{Na}\left(\operatorname{acac}^{\mathrm{x}}\right)$, with equimolar amounts of $\mathrm{Fe}(\mathrm{OTf})_{2}$ and 4-TIP $\mathrm{Ph}$ in $\mathrm{MeOH}$. This "one-pot" approach, however, is not successful for various combinations of supporting and "substrate" ligands. Thus, as described in this article, we have generated several $\mathrm{Fe}^{2+}$ complexes with $\mathrm{K}^{3}$-TIP ligands that also contain displaceable ligands (such as solvent, triflate, benzoate, and acetate) bound to the opposite face of the octahedron. These complexes resemble the resting states of $3 \mathrm{His}$ Fe dioxygenases, which feature two or three cis-labile $\mathrm{H}_{2} \mathrm{O}$ molecules. 20 In addition, it is shown that these TIP-based complexes serve as excellent precursors for the formation of monoiron complexes with three facial imidazole donors and various bound substrates, including $\beta$-diketonates and salicylates (mimics of Dke1 and SDO, respectively). Thus, the chemistry described here establishes a valuable platform for future synthetic modeling studies of nonheme Fe dioxygenases with the $3 \mathrm{His}$ facial triad.

\section{Results and Discussion}

\section{$\mathrm{Fe}^{2+}$ Complexes Containing 2-TIPPh2}

The novel 2-TIPPh2 ligand was synthesized by means of lithiation of 4,5-diphenyl-1-methylimidazole at the 2-position at $-78^{\circ} \mathrm{C}$, followed by addition of $\mathrm{PCl}_{3}$ (0.33 equiv.). Reaction of 2-TIPPh2 with Fe(OTf) ${ }_{2}$ in MeCN provided the complex [1](OTf) $)_{2}$ in $60 \%$ yield (Scheme $\underline{3}$ ). Crystals suitable for X-ray diffraction (XRD) analysis were obtained by layering a concentrated MeCN solution with diethyl ether. The structure features two symmetrically independent $[1]^{2+}$ units with nearly identical metric parameters (Table 1; details concerning the data collection and analysis of all X-ray structures are summarized in Table 4). As shown in Figure $\underline{1}$, the six-coordinate (6C) Fe ${ }^{2+}$ center is ligated by 2-TIPPh2 and three MeCN ligands in a distorted octahedral geometry. As expected, the 2-TIPPh2 ligand coordinates in a facial manner. The average Fe-N distance of $2.19 \AA$ is indicative of a high-spin $\mathrm{Fe}^{2+}$ center $(S=2)$, consistent with the measured magnetic moment of $5.2 \mu_{\mathrm{B}}$. The triflate counteranions are not bound to the metal centers, and the asymmetric unit also contains one equivalent of noncoordinated $\mathrm{Et}_{2} \mathrm{O}$.

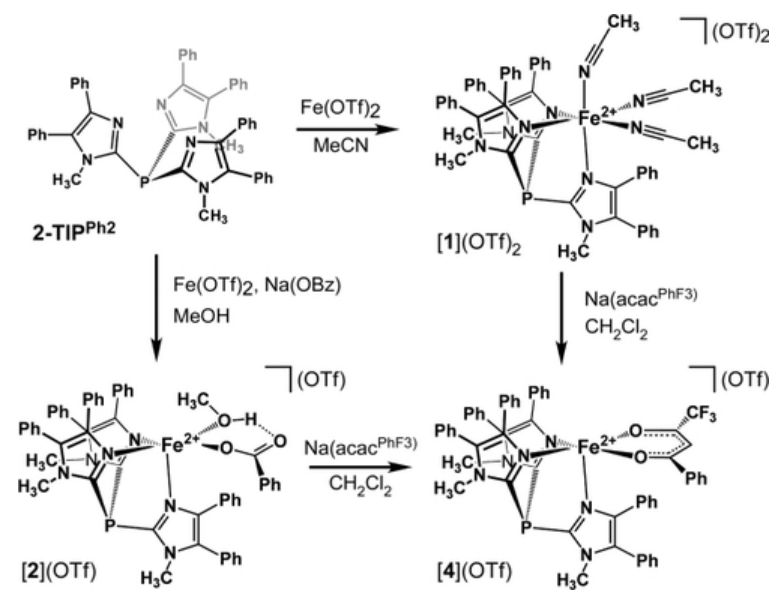




\section{Scheme 3}

Table 1. Selected metric parameters for $\left[\mathrm{Fe}^{2+}\left(\mathrm{L}_{\mathrm{N} 3}\right)(\mathrm{MeCN})_{3}\right]^{2+}$ complexes. Bond lengths in $\AA$ and angles in degrees.

\begin{tabular}{|c|c|c|c|}
\hline & {$[1](O T f)_{2} \cdot 0.5 \mathrm{Et}_{2} \mathrm{O}[\mathrm{a}]$} & {$\left[\mathrm{Fe}\left(\text { trisox }^{t \mathrm{Bu}}\right)(\mathrm{MeCN})_{3}\right]^{2+}$} & {$\left[\mathrm{Fe}\left(\mathrm{tpm}^{\mathrm{Ph} 2}\right)(\mathrm{MeCN})_{3}\right]^{2+}$} \\
\hline & & (ref.22)[b] & (ref.21)[c] \\
\hline Fe1-N2 & $2.186(1)$ & $2.257(2)$ & $2.199(2)$ \\
\hline Fe1-N4 & $2.177(1)$ & $2.205(2)$ & $2.196(2)$ \\
\hline Fe1-N6 & $2.182(1)$ & $2.215(2)$ & $2.205(3)$ \\
\hline Fe1-N7 & $2.196(1)$ & $2.163(2)$ & $2.131(3)$ \\
\hline Fe1-N8 & $2.179(1)$ & $2.131(2)$ & $2.166(2)$ \\
\hline Fe1-N9 & $2.205(1)$ & $2.171(3)$ & $2.156(3)$ \\
\hline $\mathrm{Fe}-\mathrm{N}_{\text {TIP }}$ (av.) & 2.181 & 2.226 & 2.200 \\
\hline $\mathrm{Fe}-\mathrm{N}_{\text {solv }}(\mathrm{av})$. & 2.193 & 2.155 & 2.151 \\
\hline N2-Fe1-N4 & $88.87(5)$ & $84.62(6)$ & $84.40(9)$ \\
\hline N2-Fe1-N6 & $91.43(5)$ & $82.12(6)$ & $85.84(9)$ \\
\hline N4-Fe1-N6 & $88.32(5)$ & $86.89(7)$ & $83.27(9)$ \\
\hline N7-Fe1-N8 & $85.48(5)$ & $90.25(8)$ & $87.6(1)$ \\
\hline N7-Fe1-N9 & $82.06(5)$ & $91.33(8)$ & $86.4(1)$ \\
\hline N8-Fe1-N9 & $83.23(5)$ & $86.00(8)$ & $90.3(1)$ \\
\hline
\end{tabular}

[a] Average values for the two independent, but chemically equivalent [1] ${ }^{+}$cations.

[b] trisox ${ }^{t B u}=1,1,1$-tris(4-tert-butyloxazolin-2-yl)ethane.

[c] tpm $^{\text {Ph2 }}=$ tris(3,5-diphenylpyrazol-1-yl)methane.

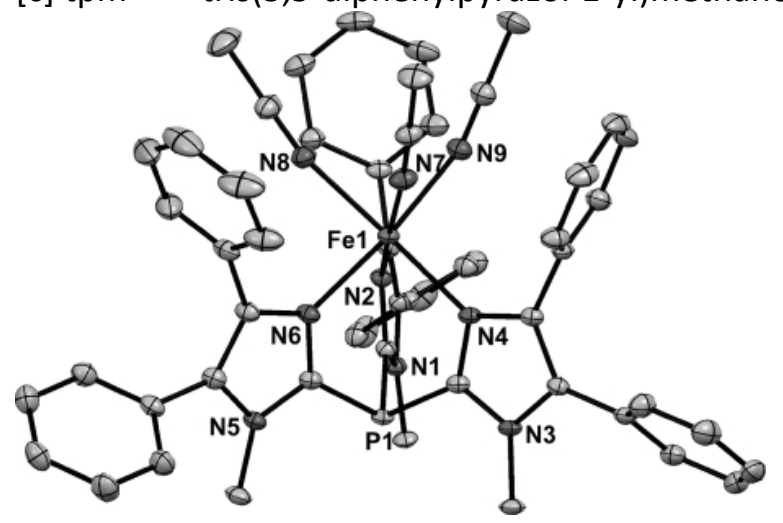

Figure 1

Thermal ellipsoid plot (50\% probability) of [1] $(\mathrm{OTf})_{2} \cdot 0.5 \mathrm{Et}_{2} \mathrm{O}$. Only one of the symmetrically inequivalent [1] (OTf $)_{2}$ units is shown. Hydrogen atoms, counteranions, and noncoordinating solvent molecules have been omitted for clarity.

Two related high-spin $\mathrm{Fe}^{2+}$ structures with $\left[\mathrm{Fe}\left(\mathrm{L}_{\mathrm{N} 3}\right)(\mathrm{MeCN})_{3}\right]^{2+}$ compositions have been reported in the literature, and their metric parameters are also provided in Table $\underline{1}$. The average Fe- $\mathrm{N}_{\text {TIP }}$ distance of $2.18 \AA$ in $[1]^{2+}$ is significantly shorter than the distances observed forthe analogous tris $(3,5-$ diphenylpyrazol-1-yl)methane (tpm $\left.{ }^{\mathrm{Ph} 2}\right) \underline{21}$ and 1,1,1-tris(4-tert-butyloxazolin-2-yl)ethane $\left(\right.$ trisox $\left.^{t \mathrm{Bu}}\right) \underline{22}$ complexes, which display average Fe-N distances of 2.20 and $2.23 \AA$, respectively. Conversely, the average $\mathrm{Fe}-\mathrm{N}_{\mathrm{MeCN}}$ distance in [1] $]^{2+}$ is approximately $0.04 \AA$ longer than those reported 
for the $\mathrm{tpm}^{\mathrm{Ph} 2}$ and trisox ${ }^{\mathrm{BB}}$ complexes. Both facts suggest that 2-TIP ${ }^{\mathrm{Ph} 2}$ is a somewhat stronger donor than other neutral N3 ligands that have appeared in the literature.

Elemental analysis performed with ground and dried crystals of [1] (OTf $)_{2}$ indicate that at least two $\mathrm{MeCN}$ ligands are removed under vacuum. In addition, evidence for Fe-OTf bonding in noncoordinating solvents was obtained by using ${ }^{19} \mathrm{~F} \mathrm{NMR}$ spectroscopy. For [1] $(\mathrm{OTf})_{2}$ in $\mathrm{CD}_{3} \mathrm{CN}$, the triflate counteranion gives rise to a sharp peak at $\delta=-79.2 \mathrm{ppm}$, which is identical to the chemical shift observed for $\left[\mathrm{NBu}_{4}\right] \mathrm{OTf}$ under the same conditions. The lengthy longitudinal relaxation time $\left(T_{1}\right.$ value) of $128 \mathrm{~ms}$ measured for this feature suggests that the triflate counteranion is only weakly associated with the $\left[\mathrm{Fe}\left(2-\mathrm{TIP}^{\mathrm{Ph} 2}\right)\right]^{2+}$ unit in MeCN. In contrast, the ${ }^{19} \mathrm{~F} \mathrm{NMR}$ spectrum of $[1](\mathrm{OTf})_{2}$ in $\mathrm{CD}_{2} \mathrm{Cl}_{2}$ exhibits a broad feature at $\delta=-60.9 \mathrm{ppm}$ with a short $T_{1}$ value of $14 \mathrm{~ms}$ (Figure S1 in the Supporting Information), which indicates that the triflate ion is directly bound to the Fe center.

Reaction of equimolar amounts of $\mathrm{Fe}(\mathrm{OTf})_{2}, 2-\mathrm{TIP}^{\mathrm{Ph} 2}$, and sodium benzoate ( $\mathrm{NaOBz}$ ) in $\mathrm{MeOH}$ provided the colorless complex [Fe(2-TIP Ph2 $)(\mathrm{OBz})(\mathrm{MeOH})] \mathrm{OTf}([2] \mathrm{OTf})$, as shown in Scheme $\underline{3}$. X-ray-quality crystals were obtained from a solution of [2]OTf in $\mathrm{MeOH}$ layered with pentane. The resulting structure reveals a pentacoordinate $(5 \mathrm{C})$ iron(II) center with a $\mathrm{K}^{3}-2-\mathrm{TIP} \mathrm{Ph}^{\mathrm{Ph}}$ ligand, monodentate benzoate ligand, and bound solvent (Figure 2). In addition to the second-sphere triflate anion, the asymmetric unit also contains four $\mathrm{MeOH}$ molecules that do not directly interact with the [2] ${ }^{+}$cation. The complex adopts a distorted square-pyramidal geometry $(\tau=0.25 \underline{23})$ with an $\mathrm{O}_{2} \mathrm{~N}_{2}$ pseudobasal plane. Two phenyl rings of the 2-TIPPh2 ligand lie across the vacant coordination site (i.e., parallel to the plane of the benzoate ligand), which prevents further solvent binding. The $\mathrm{Fe}-\mathrm{N}_{\mathrm{TIP}}$ and $\mathrm{Fe}-\mathrm{O}$ distances are typical for highspin $\mathrm{Fe}^{2+}$ centers (Table 2 ). The $\mathrm{H}$ atom of the coordinated $\mathrm{MeOH}$ molecule was found objectively and refined. The resulting $02 \cdots 03$ distance of $2.610(2) \AA$ and $\mathrm{H} 3 \cdots \mathrm{O} 2$ distance of $1.81(1) \AA$ are indicative of an intramolecular hydrogen bond that closes a six-membered ring.

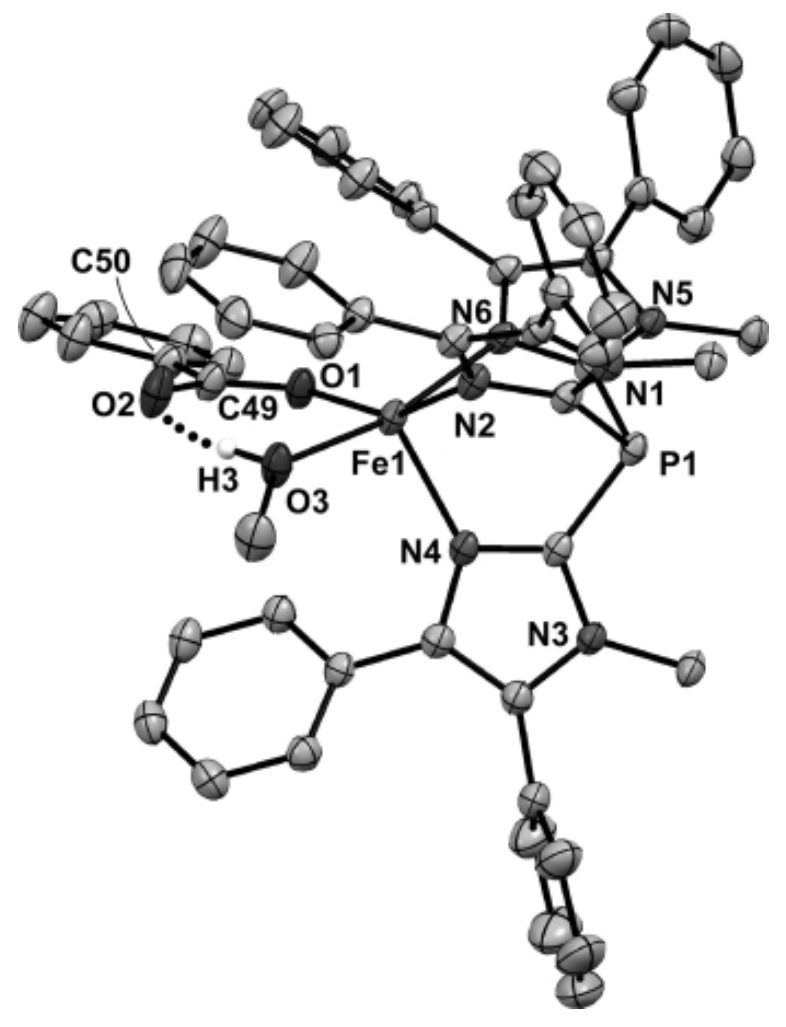




\section{Figure 2}

Thermal ellipsoid plot (50\% probability) derived from[2]OTf-4MeOH. Non-coordinating solvent molecules, counteranions, and most $\mathrm{H}$ atoms have been omitted for clarity. The dotted line indicates the hydrogen-bonding interaction between $\mathrm{H} 3$ of the $\mathrm{MeOH}$ ligand and $\mathrm{O} 2$ of the benzoate anion.

Table 2. Selected metric parameters for ferrous carboxylate complexes [2]OTf·4MeOH, $3 \cdot 2 \mathrm{CH}_{2} \mathrm{Cl}_{2}$, and [5] $\mathrm{BPh}_{4} \cdot 3 \mathrm{MeOH}$. Bond lengths in $\AA$ and angles in degrees.

\begin{tabular}{|l|l|l|l|}
\hline & {$[2] O T f \cdot 4 M e O H$} & $3 \cdot 2 \mathrm{CH}_{2} \mathrm{Cl}_{2}[\mathrm{a}]$ & {$[5] \mathrm{BPh}_{4} \cdot \mathbf{3 M e O H}$} \\
\hline Fe1-N2 & $2.124(2)$ & $2.129(3)$ & $2.193(4)$ \\
\hline Fe1-N4 & $2.127(2)$ & $2.111(3)$ & $2.195(4)$ \\
\hline Fe1-N6 & $2.226(2)$ & $2.210(3)$ & $2.186(4)$ \\
\hline Fe-NLN3 (av.) & 2.158 & 2.150 & 2.191 \\
\hline Fe1-O1 & $2.011(1)$ & $1.977(3)$ & $2.245(4)$ \\
\hline Fe1-O2 & & & $2.256(4)$ \\
\hline Fe1-O3(N7) & $2.105(1)$ & $2.144(3)$ & $2.077(4)$ \\
\hline O1-C carboxyl & $1.273(2)$ & $1.271(5)$ & $1.267(6)$ \\
\hline O2-C carboxyl & $1.254(2)$ & $1.244(4)$ & $1.268(6)$ \\
\hline N2-Fe1-N4 & $93.94(6)$ & $94.3(1)$ & $90.2(2)$ \\
\hline N2-Fe1-N6 & $85.36(6)$ & $80.7(1)$ & $90.3(2)$ \\
\hline N4-Fe1-N6 & $91.69(6)$ & $87.4(1)$ & $90.6(2)$ \\
\hline O1-Fe1-N2 & $153.44(6)$ & $152.4(1)$ & $105.9(2)$ \\
\hline O1-Fe1-N4 & $112.06(6)$ & $110.9(1)$ & $91.1(2)$ \\
\hline O1-Fe1-N6 & $88.38(6)$ & $89.2(1)$ & $163.7(2)$ \\
\hline O1-Fe1-O3(N7) & $87.64(6)$ & $98.7(1)$ & $84.6(2)$ \\
\hline N2-Fe1-O3(N7) & $93.34(6)$ & $89.0(1)$ & $93.9(2)$ \\
\hline N4-Fe1-O3(N7) & $100.01(6)$ & $96.6(1)$ & $174.8(2)$ \\
\hline N6-Fe1-O3(N7) & $168.29(6)$ & $169.2(1)$ & $92.6(2)$ \\
\hline$\tau$ value & 0.25 & 0.28 & $\mathrm{~N} / \mathrm{A}$ \\
\hline
\end{tabular}

[a] Data from the literature. 24 The $\mathrm{N}$ and $\mathrm{O}$ atoms in the $3 \cdot 2 \mathrm{CH}_{2} \mathrm{Cl}_{2}$ structure were renumbered to correspond to the numbering scheme used for the other complexes.

Complex [2] ${ }^{+}$resembles the structure of $\left[\mathrm{Fe}\left({ }^{\mathrm{Ph}, \mathrm{Me}} \mathrm{Tp}\right)(\mathrm{OBz})\left({ }^{\mathrm{Ph}, \mathrm{Me}} \mathrm{pyz}\right)\right]\left(\mathbf{3}\right.$; in which ${ }^{\mathrm{Ph}, \mathrm{Me}}$ pyz = 3-phenyl-5methylpyrazole) published by Fujisawa and co-workers.24 Both complexes feature a distorted squarepyramidal geometry with a monodentate benzoate ion linked to a neutral ligand by means of an intramolecular hydrogen bond. As shown in Table $\mathbf{2}$, the metric parameters of [2] $]^{+}$and $\mathbf{3}$ are quite similar; indeed, the average Fe- $\mathrm{N}_{\text {TIP }}$ distance of $2.16 \AA$ found for [2] $]^{+}$is only $0.01 \AA$ longer than the average Fe- $\mathrm{N}_{T p}$ distance in 3. This result is consistent with our previous study of $\left[\mathrm{Fe}^{2+}\left(\mathrm{L}_{\mathrm{N} 3}\right)(\beta-\right.$ diketonato) $]^{+/ 0}$ complexes that found only slight differences (on average) between $\mathrm{Fe}-\mathrm{N}_{\text {TIP }}$ and $\mathrm{Fe}-$ $\mathrm{N}_{\mathrm{Tp}}$ bond lengths in $5 \mathrm{C}$ species, despite the different charges of the supporting ligands. $\underline{19}$

Starting from either of these two Fe(2-TIP Ph2 $)$ precursors - [1] (OTf $)_{2}$ or [2]OTf - we were able to generate the complex [Fe(2-TIP $\left.\left.{ }^{\text {Ph2 }}\right)\left(\mathrm{acac}^{\mathrm{PhF} 3}\right)\right] \mathrm{OTf}\left([4] \mathrm{OTf}\right.$; Scheme $\underline{\mathbf{3}}$; in which $\mathrm{acac}^{\mathrm{PhF3}}=$ anion of 4,4,4trifluoro-1-phenyl-1,3-butanedione). The acac ${ }^{\text {PhF3 }}$ ligand was selected for two reasons: (i) it is a viable 
Dke1 substrate, $\underline{\mathbf{2 5}}$ and (ii) previous studies in our laboratory found that $\left[\mathrm{Fe}\left(\mathrm{L}_{\mathbf{N} 3}\right)\left(\mathrm{acac} \mathrm{c}^{\mathrm{PhF} 3}\right)\right]^{+/ 0}$ complexes exhibit intense $\mathrm{Fe}^{2+} \rightarrow$ acac $^{\text {PhF3 }}$ MLCT bands that serve as useful spectroscopic markers. 19 For both $\mathrm{Fe}\left(2-\mathrm{TIP}^{\mathrm{Ph} 2}\right)$ precursors, reaction with $\mathrm{Na}\left(\mathrm{acac}^{\mathrm{PhF}}\right)$ provides a deep purple solution that displays an absorption manifold centered at $502 \mathrm{~nm}\left(\epsilon=700 \mathrm{M}^{-1} \mathrm{~cm}^{-1}\right.$; see Figure S2 in the Supporting Information). Not surprisingly, the[4]OTf spectrum closely resembles the one published for [Fe(4$\operatorname{TIPh}^{\mathrm{Ph}}\left(\right.$ acac $\left.\left.^{\mathrm{PhF3}}\right)\right] \mathrm{OTf}$, although the absorption features are blueshifted in the former by approximately $400 \mathrm{~cm}^{-1} . \underline{19}$

Crystals of [4]OTf were obtained from the reaction of [1](OTf) $)_{2}$ and $\mathrm{Na}\left(\mathrm{acac}^{\mathrm{PhF}}\right.$ ) in $\mathrm{CH}_{2} \mathrm{Cl}_{2}$, followed by crystallization in $\mathrm{CH}_{2} \mathrm{Cl}_{2}$ /pentane. The asymmetric unit contains two independent units with virtually identical structures. As shown in Figure $\mathbf{3}$, the $5 \mathrm{C} \mathrm{Fe}^{2+}$ center is coordinated to the 2-TIP ${ }^{\mathrm{Ph}}$ and acac $^{\text {PhF3 }}$ ligands in a distorted trigonal-bipyramidal geometry $(\tau=0.51)$ with the $O$ atom proximal to the $\mathrm{CF}_{3}$ group (O1) in the axial position. The metric parameters of [4]OTf are not significantly different from those reported previously for $\left[\mathrm{Fe}^{2+}\left({ }^{\mathrm{Ph} 2} \mathrm{Tp}\right)\left(\mathrm{acac}^{\mathrm{PhF} 3}\right)\right]$ and $\left[\mathrm{Fe}^{2+}\left(4-\mathrm{TIP}^{\mathrm{Ph}}\right)\left(\mathrm{acac}^{\mathrm{PhF} 3}\right)\right] \mathrm{OTf} . \underline{19}$

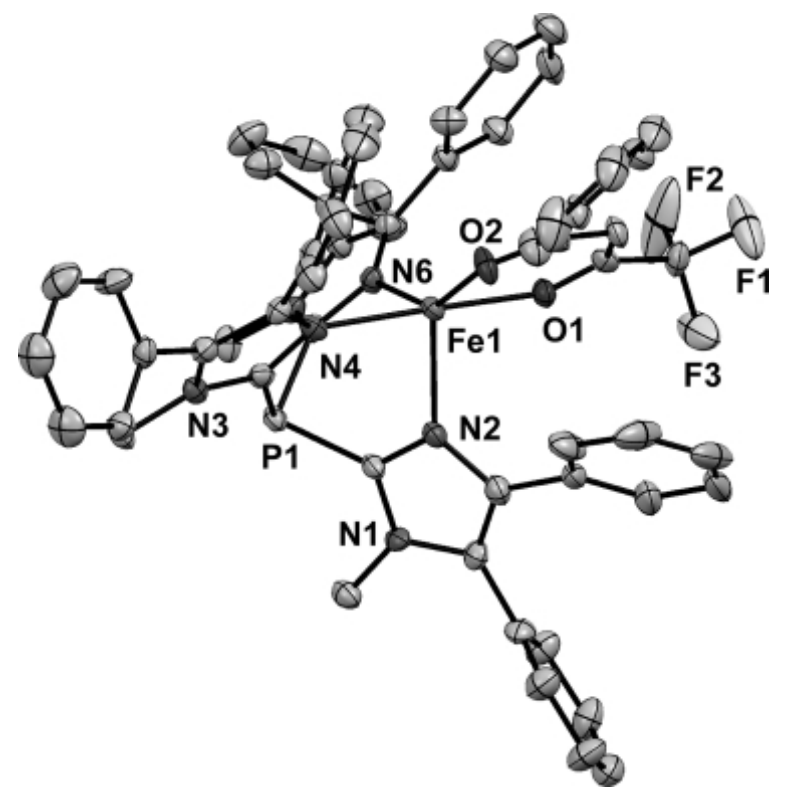

Figure 3

Thermal ellipsoid plot (50\% probability) derived from[4]OTf $2 \mathrm{CH}_{2} \mathrm{Cl}_{2}$. Non-coordinating solvent molecules, counteranions, and most $\mathrm{H}$ atoms have been omitted for clarity. Only one of the two independent $[5]^{+}$units is shown. Selected bond lengths $[\AA]$ and angles $\left[{ }^{\circ}\right]$ for this unit: Fe1-01 2.089(3), Fe1-O2 1.973(3), Fe1-N2 2.118(4), Fe1-N4 2.190(4), Fe1-N6 2.118(4); O1-Fe1-O2 87.2(1), O1-Fe1N2 91.0(2), O1-Fe1-N4 176.4(2), O1-Fe1-N6 89.5(2), O2-Fe1-N2 120.4(2), O2-Fe1-N4 96.5(2), O2Fe1-N6 146.3(2).

The solution structures of [2]OTf and [4]OTf in $\mathrm{CD}_{2} \mathrm{Cl}_{2}$ were probed using ${ }^{1} \mathrm{H}$ NMR spectroscopy, and the observed chemical shifts, peak integrations, and $T_{1}$ values are summarized in Table $\underline{3}$. The three imidazole ligands are spectroscopically equivalent in solution due to dynamic averaging of the ligand positions on the NMR spectroscopic timescale. The 2-TIP ${ }^{\mathrm{Ph} 2}$-derived resonances were assigned with the help of peak integrations and by making two assumptions: (i) $T_{1}$ values follow the order ortho < meta < para for each phenyl ring, $\underline{13 \mathrm{c}}, \underline{19}$ and (ii) $T_{1}$ values of the 4-Ph protons are shorter 
than the corresponding protons on the 5-Ph ring. Thus, the fast-relaxing peaks ( $\left.T_{1} \approx 1 \mathrm{~ms}\right)$ near -20 ppm were attributed to the ortho protons of the 4-phenyl 2-TIP ${ }^{\mathrm{Ph} 2}$ substituents, which are positioned near the $\mathrm{Fe}^{2+}$ center. The peaks with the largest integration at $(21 \pm 1) \mathrm{ppm}$ were assigned to the $1-\mathrm{N}$ Me protons. The remaining resonances were then identified as the benzoate and acac ${ }^{\text {PhF3 }}$ groups of [2]OTf and [4]OTf, respectively, by using the relative $T_{1}$ values to assign the phenyl resonances of both ligands.

Table 3. Summary of ${ }^{1} \mathrm{H}$ NMR spectroscopic parameters for [2]OTf and [4]OTf in $\mathrm{CD}_{2} \mathrm{Cl}_{2}$.

\begin{tabular}{|l|l|l|l|l|l|}
\hline [2]OTf & & & [4]OTf & & \\
\hline Resonance & $\boldsymbol{\delta}$ [ppm] & $\boldsymbol{T}_{\mathbf{1}}$ [ms] & Resonance & $\boldsymbol{\delta}$ [ppm] & $\boldsymbol{T}_{\mathbf{1}}$ [ms] \\
\hline$o-4-\mathrm{Ph}$ & -21.0 & 1.1 & $o-4-\mathrm{Ph}$ & -16.0 & 0.4 \\
\hline$m-4-\mathrm{Ph}$ & 6.7 & 12.0 & $m-4-\mathrm{Ph}$ & 5.2 & 4.7 \\
\hline$p-4-\mathrm{Ph}$ & 9.0 & 31.6 & $p-4-\mathrm{Ph}$ & 9.3 & 13.3 \\
\hline$o-5-\mathrm{Ph}$ & 2.6 & 31.5 & $o-5-\mathrm{Ph}$ & 2.4 & 13.7 \\
\hline$m-5-\mathrm{Ph}$ & 6.3 & 159 & $m-5-\mathrm{Ph}$ & 6.1 & 88.2 \\
\hline$p-5-\mathrm{Ph}$ & 5.2 & 238 & $p-5-\mathrm{Ph}$ & 5.0 & 120 \\
\hline$N-1-\mathrm{Me}$ & 21.9 & 15.7 & $N-1-\mathrm{Me}$ & 20.2 & 5.9 \\
\hline$o-\mathrm{OBz}$ & 34.8 & 3.2 & acac $o-\mathrm{Ph}$ & 22.6 & 1.7 \\
\hline$m-\mathrm{OBz}$ & 19.0 & 37.0 & acac $m-\mathrm{Ph}$ & 9.5 & 20.0 \\
\hline$p-\mathrm{OBz}$ & 10.6 & 67.6 & acac $p-\mathrm{Ph}$ & 17.3 & 45.5 \\
\hline & & & acac $\mathrm{H}$ & 39.4 & 0.8 \\
\hline
\end{tabular}

$\mathrm{Fe}^{2+}$ Complexes Containing 4-TIP ${ }^{\mathrm{Ph}}$

The complex $\left[\mathrm{Fe}\left(4-\mathrm{TIP}^{\mathrm{Ph}}\right)(\mathrm{OAc})(\mathrm{MeOH})\right] \mathrm{BPh}_{4}\left([5] \mathrm{BPh}_{4}\right)$ was generated by addition of $\mathrm{NaBPh}_{4}$ to a solution of $\mathrm{Fe}(\mathrm{OAC})_{2}$ and 4-TIP ${ }^{\mathrm{Ph}}$ in $\mathrm{MeOH}$, which resulted in the immediate formation of a white precipitate (Scheme 4). The IR spectrum of the isolated solid revealed a peak at $3259 \mathrm{~cm}^{-1} \mathrm{from}$ the $\mathrm{V}(\mathrm{N}-\mathrm{H})$ stretch of the 4-TIP Ph ligands, along with acetate-derived features at 1562 and $1402 \mathrm{~cm}^{-1}$. The 4-TIP ${ }^{\mathrm{Ph}}$-derived resonances in the ${ }^{1} \mathrm{H}$ NMR spectrum largely followed the pattern reported previously for $\left[\mathrm{Fe}^{2+}\left(4-\mathrm{TIP}^{\mathrm{Ph}}\right)\left(\mathrm{acac}^{\mathrm{X}}\right)\right]^{+}$complexes.19 The acetate ligand of [5]BPh 4 exhibited a downfield signal at $\delta=+105$ ppm.

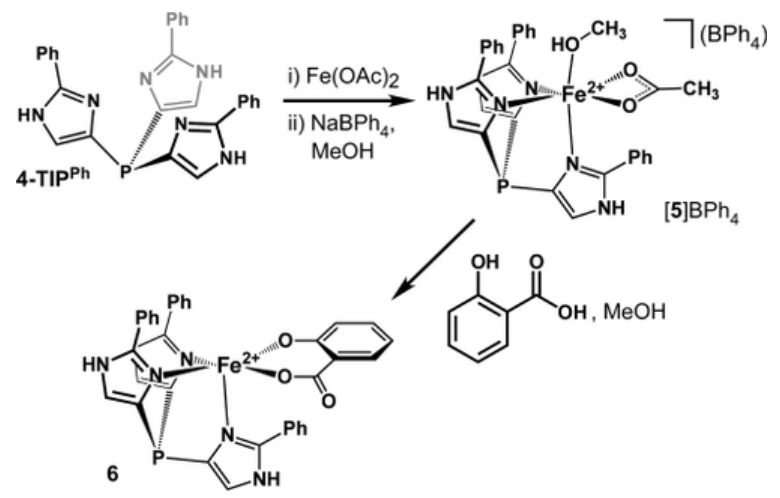

\section{Scheme 4}

X-ray-quality crystals of [5] $\mathrm{BPh}_{4}$ were prepared by slowly cooling a solution of [5] $\mathrm{BPh}_{4}$ in $\mathrm{MeOH}$; the $[5]^{+}$cation is shown in Figure $\underline{4}$ and the corresponding bond lengths and angles are provided in Table $\underline{\mathbf{2}}$. 
The high-spin $\mathrm{Fe}^{2+}$ center is hexacoordinate with a facially coordinating 4-TIP Ph ligand. The Fe$\mathrm{N}_{\text {TIP }}$ distances in $[5]^{+}$are quite similar to those found for $[\mathbf{1}]^{2+}$ and $[2]^{+}$, which suggests that the 4TIP ${ }^{\mathrm{Ph}}$ and 2-TIPP2 ligands possess comparable donor properties. The $\mathrm{k}^{2}$-acetate ligand coordinates in a symmetric manner with nearly identical Fe-O $\mathrm{O}_{\text {acetate }}$ distances of 2.251(6) $\AA$. The remaining site is occupied by a solvent molecule trans to N4 with a relatively short Fe- $\mathrm{O}_{\mathrm{MeOH}}$ distance of 2.077(4) $\AA$. The crystal structure of [5] $\mathrm{BPh}_{4} \cdot 3 \mathrm{MeOH}$ also features an extensive hydrogen-bonding network. As shown in Figure 4, the coordinated acetate and $\mathrm{MeOH}$ moieties participate in hydrogen-bonding interactions with three $\mathrm{MeOH}$ "chaperones" that comprise a second-sphere shell surrounding one face of the $[5]^{+}$octahedron. In addition, the $\mathrm{MeOH}$ molecules that serve as hydrogen-bond donors to the acetate ligand also act as hydrogen-bond acceptors for two $\mathrm{H}-\mathrm{N}_{\text {imidazole }}$ groups on adjacent [5] ${ }^{+}$cations.

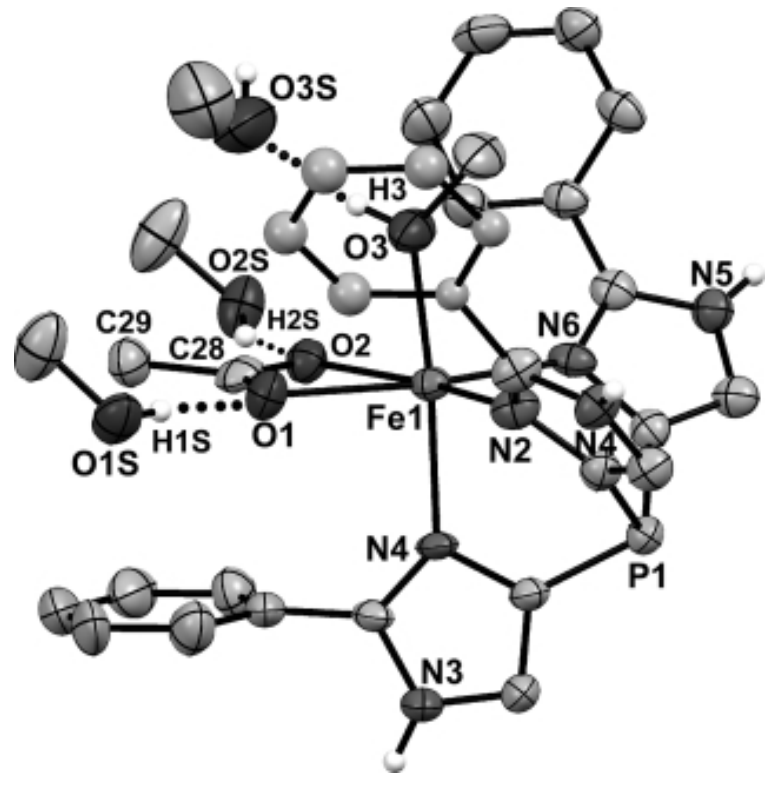

Figure 4

Thermal ellipsoid plot (50\% probability) derived from[5] $\mathrm{BPh}_{4} \cdot 3 \mathrm{MeOH}$. The $\mathrm{BPh}_{4}$ counteranion and most $\mathrm{H}$ atoms have been omitted for clarity. The dotted lines signify the hydrogen-bonding interactions between the coordinated acetate and $\mathrm{MeOH}$ ligands and three second-sphere solvent molecules. Note: Ellipsoids are not shown for the proximal 2-Ph substituent due to disorder.

Significantly, we found that [5]BPh 4 provides access to iron(II) salicylate (sal) species that mimic the enzyme-substrate complex of SDO. The complex [Fe(4-TIP $\left.\left.{ }^{\mathrm{Ph}}\right)(\mathrm{sal})\right](6)$ was prepared by mixing [5]BPh 4 with salicylic acid (1 equiv.) in $\mathrm{MeOH}$, followed by layering with $\mathrm{MeCN}$ (Scheme $\underline{4}$ ). As shown in Figure $\underline{\mathbf{5}}$, the $\mathrm{X}$-ray crystal structure of $\mathbf{6}$ reveals a neutral $5 \mathrm{C} \mathrm{Fe}{ }^{2+}$ complex with a geometry between square pyramidal and trigonal bipyramidal $(\tau=0.35)$. The dianionic salicylate ligand coordinates in a bidentate fashion with Fe-O bond lengths of 1.958(1) and 2.060(1) A for the phenolate and carboxylate donors, respectively. To the best of our knowledge, 6 represents the first structurally characterized iron(II) salicylate complex in the chemical literature.26 


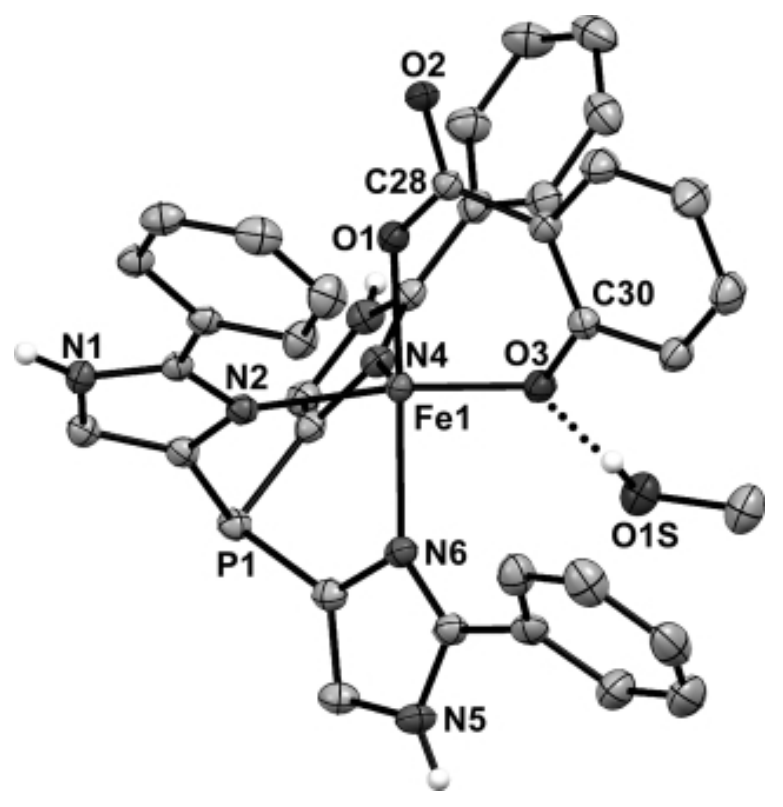

Figure 5

Thermal ellipsoid plot (50\% probability) derived from 6.MeOH·MeCN. The noncoordinating MeCN and most $\mathrm{H}$ atoms have been omitted for clarity. The dotted line represents the hydrogen-bonding interaction between the salicylate ligand and $\mathrm{MeOH}$. Selected bond lengths $[\AA]$ and angles $\left[{ }^{\circ}\right]$ : Fe1-01 2.060(1), Fe1-O3 1.958(1), Fe1-N2 2.135(1), Fe1-N4 2.150(1), Fe1-N6 2.183(1), O1-C28 1.257(2), O2-

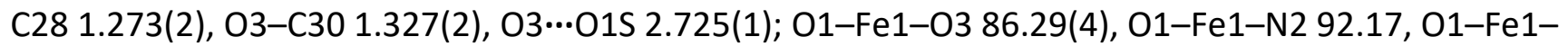
N4 96.90(4), O1-Fe1-N6 168.66(4), O3-Fe1-N2 147.75(4), O3-Fe1-N4 117.46(4), O3-Fe1-N6 91.71(4).

As with [5] BPh $4 \cdot 3 \mathrm{MeOH}$, the lattice of 6 exhibits numerous hydrogen-bonding interactions (see Scheme $\underline{5}$ ). The uncoordinated oxygen atom of the carboxylate $(02)$ forms hydrogen bonds with two $\mathrm{H}-\mathrm{N}$ groups belonging to adjacent 4-TIP ${ }^{\mathrm{Ph}}$ ligands. These interactions account for the fact that $\mathrm{O} 2-\mathrm{C} 28$ is unexpectedly longer than $01-\mathrm{C} 28$ [1.273(2) vs. 1.257(2), respectively], which indicates that the negative charge is delocalized over the carboxylate moiety. The crystal also contains noncoordinating $\mathrm{MeCN}$ and $\mathrm{MeOH}$ molecules (one of each); the latter serves as a hydrogen-bond donor to the phenolate oxygen atom (O3) of the salicylate, while acting as a hydrogen-bond acceptor to an imidazole $\mathrm{H}-\mathrm{N}$ group. Thus, in this structure, $\mathrm{MeOH}$ behaves in a manner similar to second-sphere residues in dioxygenase active sites, which often play a crucial role in stabilizing metal-bound substrates through noncovalent interactions. $\underline{27}$ 


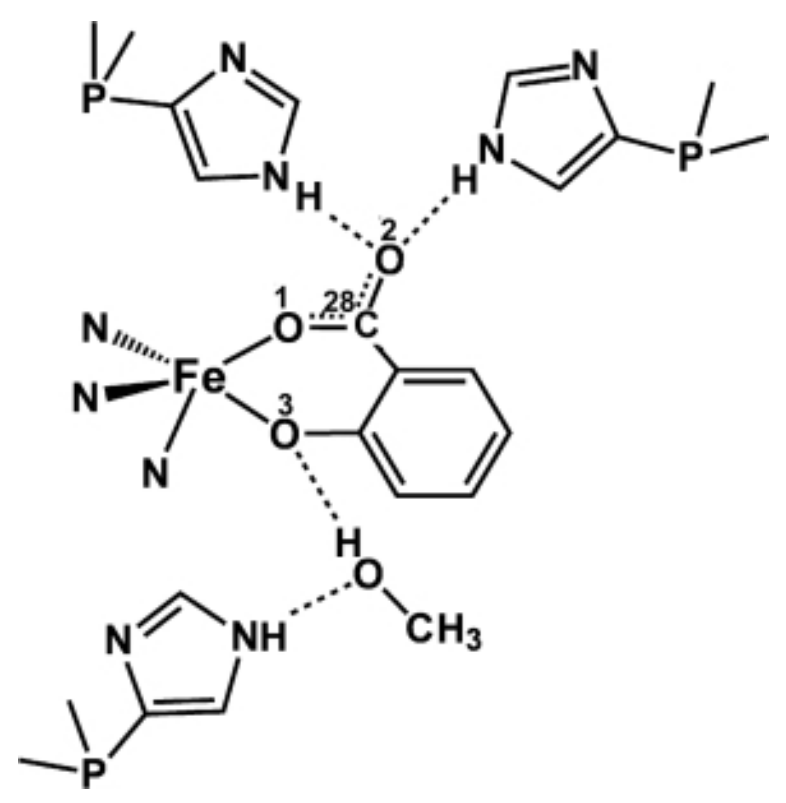

\section{Scheme 5}

Hydrogen-bonding network in the solid-state structure of 6.

\section{Conclusion}

This paper has described the synthesis and X-ray structural characterization of iron(II) complexes supported by tris(imidazolyl)phosphane ligands (2-TIP ${ }^{\mathrm{Ph} 2}$ and 4-TIP ${ }^{\mathrm{Ph}}$ ). Three of the complexes [1] (OTf $)_{2},[2] \mathrm{OTf}$, and [5]BPh 4 - feature easily displaced ligands, such as solvent molecules and/or carboxylates, in the coordination sites trans to the TIP chelate. These complexes exhibit variability in their coordination numbers $\left(5 \mathrm{C}\right.$ or $6 \mathrm{C}$ ) and carboxylate binding modes $\left(\mathrm{k}^{1}\right.$ or $\left.\mathrm{k}^{2}\right)$. Intra- and intermolecular hydrogen-bonding interactions between the ligands and solvent are evident in the solid-state structures of each complex \{with the exception of [1](OTf $\left.)_{2}\right\}$ In particular, the presence of unprotected imidazole groups in [5] $\mathrm{BPh}_{4}$ gives rise to an extensive hydrogen-bonding network in which second-sphere $\mathrm{MeOH}$ molecules form bridges between acetate ligands andH- $\mathrm{N}_{\text {imid }}$ groups from neighboring $[5]^{+}$units.

Like the resting states of the enzymatic active sites, these "precursor" complexes are intended to serve as scaffolds that permit various substrate ligands to coordinate to the iron(II) center. The versatility of this approach was demonstrated by the formation of the Dke1 model [4]OTf from the reaction of $\mathrm{Na}\left(\text { acac }^{\mathrm{PhF}} \text { ) with the 2-TIP }{ }^{\mathrm{Ph} 2} \text {-based complexes [1] (OTf }\right)_{2}$ and [2]OTf. Similarly, the SDO model 6 was generated through the direct reaction of [5] $\mathrm{BPh}_{4}$ with salicylic acid. The facile formation of [4]OTf and $\mathbf{6}$ indicates that the TIP ligands are resistant to displacement by strong, anionic ligands. This is significant because half-sandwich ferrous complexes with neutral $L_{\mathrm{N} 3}$ ligands, such as trispyrazolylmethanes, have been shown to suffer from high lability and a tendency to decompose to the more stable bis-ligand species.21 The relatively short Fe- $\mathrm{N}_{\text {TIP }}$ bond lengths found in our series of complexes suggest that the TIP ligands bind tightly to the iron centers. Thus, the precursor complexes described here provide a robust platform for the development of synthetic models of dioxygenases with the 3 His facial triad. 


\section{Experimental Section}

General Procedures: All reagents and solvents were purchased from commercial sources and used as received unless otherwise noted. $\mathrm{MeCN}$ and $\mathrm{CH}_{2} \mathrm{Cl}_{2}$ were purified and dried using a Vacuum Atmospheres solvent purification system. The compounds 4,5-diphenyl-1-methylimidazole 28 and 4$\mathrm{TIP}^{\mathrm{Ph}[16 \mathrm{~h}]}$ were prepared according to literature procedures. The synthesis and handling of air-sensitive materials were carried out under an inert atmosphere using a Vacuum Atmospheres Omni-Lab glovebox equipped with a freezer set to $-30^{\circ} \mathrm{C}$. Elemental analyses were performed at Midwest Microlab, LLC in Indianapolis, IN. Infrared (IR) spectra of solid samples were measured with a Thermo Scientific Nicolet iS5 FTIR spectrometer equipped with the iD3 attenuated total reflectance accessory. UV/Vis spectra were obtained with an Agilent 8453 diode array spectrometer. NMR spectra were recorded on a Varian $400 \mathrm{MHz}$ spectrometer. ${ }^{19} \mathrm{~F}$ NMR spectra were referenced using the benzotrifluoride peak at $-63.7 \mathrm{ppm}$. ${ }^{31} \mathrm{P}$ NMR spectra were referenced to external $\mathrm{H}_{3} \mathrm{PO}_{4}(\delta=0 \mathrm{ppm})$. Magnetic susceptibility measurements were carried out using the Evans NMR method.

2-TIP Ph2: 4,5-Diphenyl-1-methylimidazole $(6.81 \mathrm{~g}, 29.1 \mathrm{mmol})$ was dissolved in THF (175 $\mathrm{mL})$ and the solution was purged with argon for $25 \mathrm{~min}$. The flask was cooled to $-78^{\circ} \mathrm{C}$ and $n \mathrm{BuLi}(32.0 \mathrm{mmol})$ was added dropwise. The solution was stirred for $30 \mathrm{~min}$ at $-78{ }^{\circ} \mathrm{C}$ and then for $30 \mathrm{~min}$ at room temperature. The reaction was cooled again to $-78^{\circ} \mathrm{C}$ and $\mathrm{PCl}_{3}(0.850 \mathrm{~mL}, 9.74 \mathrm{mmol})$ was added slowly. The mixture was allowed to slowly warm to room temp. over the course of several hours, and then $30 \% \mathrm{NH}_{4} \mathrm{OH}(75 \mathrm{~mL})$ was added and stirred for $1 \mathrm{~h}$. The layers were separated and the aqueous layer was extracted with THF $(2 \times 35 \mathrm{~mL})$. The combined THF layers were washed with $\mathrm{H}_{2} \mathrm{O}$ and brine (50 $\mathrm{mL}$ each), dried with $\mathrm{MgSO}_{4}$, and the solvent was removed under vacuum. The orange residue was triturated with pentane and washed with methanol, thereby providing a fine white powder (1.66 g); yield $24 \%$. $\mathrm{C}_{48} \mathrm{H}_{39} \mathrm{~N}_{6} \mathrm{P}$ (730.8): calcd. C 78.88, H 5.38, N 11.50; found C 78.05, H 5.83, N 11.03. The disagreement indicates that small amounts of impurities are present. ${ }^{1} \mathrm{H} \mathrm{NMR}\left(400 \mathrm{MHz}, \mathrm{CDCl}_{3}\right): \delta=$ $7.48(\mathrm{~m}, 12 \mathrm{H}, \mathrm{Ar}-\mathrm{H}), 7.40(\mathrm{~m}, 6 \mathrm{H}, \mathrm{Ar}-\mathrm{H}), 7.17(\mathrm{~m}, 12 \mathrm{H}, \mathrm{Ar}-\mathrm{H}), 3.64\left(\mathrm{~s}, 9 \mathrm{H}, \mathrm{CH}_{3}\right) \mathrm{ppm} .{ }^{13} \mathrm{C} \mathrm{NMR}(100$ $\left.\mathrm{MHz}, \mathrm{CDCl}_{3}\right): \delta=140.5,140.0,139.9,134.8,133.6,131.1,131.0,129.2,129.0,128.2,126.9,126.5,33.4$ ppm. ${ }^{31} \mathrm{P} \mathrm{NMR}\left(162 \mathrm{MHz}, \mathrm{CDCl}_{3}\right): \delta=-56.6 \mathrm{ppm}$. IR (neat): $\tilde{\nabla}=3053,2940,2863,1601,1503,1442$, $1363,1071,1024,961 \mathrm{~cm}^{-1}$.

[Fe(2-TIP $\left.\left.{ }^{\mathrm{Ph} 2}\right)(\mathrm{MeCN})_{3}\right](\mathrm{OTf})_{2}\left\{[1](\mathrm{OTf})_{2}\right\}: 2-\mathrm{TIP}^{\mathrm{Ph} 2}(1.32 \mathrm{~g}, 1.81 \mathrm{mmol})$ and Fe(OTf) 2 (670 $\left.\mathrm{mg}, 1.90 \mathrm{mmol}\right)$ were mixed in $\mathrm{CH}_{3} \mathrm{CN}(20 \mathrm{~mL})$ and stirred until the solution had become clear (about $3 \mathrm{~h}$ ). The solution was filtered and layered with excess $\mathrm{Et}_{2} \mathrm{O} ; \mathrm{X}$-ray-quality crystals formed after one day. The white crystals were collected and dried under vacuum to provide $1.31 \mathrm{~g}$ of material; yield $60 \%$. Elemental analysis showed that at least two of thecoordinated $\mathrm{CH}_{3} \mathrm{CN}$ ligands are removed upon drying. $\mathrm{C}_{50} \mathrm{H}_{39} \mathrm{~F}_{6} \mathrm{FeN}_{6} \mathrm{O}_{6} \mathrm{PS}_{2} \cdot \mathrm{CH}_{3} \mathrm{CN}$ (1125.9): calcd. C 55.47, $\mathrm{H}$ 3.76, N 8.71; found C 55.02, H 3.90, N 8.68. IR (neat): $\tilde{V}=3048,2932,2283[\mathrm{v}(\mathrm{C} \equiv \mathrm{N})], 1466,1444,1257,1222,1145,1028,983 \mathrm{~cm}^{-1}$.

[Fe(2-TIP ${ }^{\text {Ph2 }}$ )(OBz)(MeOH)]OTf ([2]OTf): 2-TIP Ph2 (779 mg, $\left.1.07 \mathrm{mmol}\right), \mathrm{NaOBz}$ (155 mg, $1.07 \mathrm{mmol}$ ), and $\mathrm{Fe}(\mathrm{OTf})_{2}$ (378 $\mathrm{mg}, 1.07 \mathrm{mmol}$ ) were combined in $\mathrm{MeOH}(12 \mathrm{~mL})$. After stirring for several hours the precipitate was removed by filtration and the filtrate was reduced to about $5 \mathrm{~mL}$ in volume. Layering with pentane afforded the desired product as a white crystalline material (116 mg); yield $11 \%$. X-ray diffraction analysis revealed four uncoordinated $\mathrm{MeOH}$ molecules in the resulting structure, and elemental analysis indicated that two solvent molecules remain after drying under vacuum. 
$\mathrm{C}_{57} \mathrm{H}_{47} \mathrm{~F}_{3} \mathrm{FeN}_{6} \mathrm{O}_{6} \mathrm{PS} \cdot 2 \mathrm{CH}_{3} \mathrm{OH}$ (1152.0): calcd. C 61.51, H 4.81, N 7.30; found C 61.35, H 4.48, N 7.07. IR (neat): $\widetilde{V}=3043,2953,1598,1551,1443,1370,1258,1153,1029,981 \mathrm{~cm}^{-1}$.

[Fe(2-TIP $\left.{ }^{\text {Ph2 }}\right)\left(\right.$ acac $\left.\left.^{\text {PhF3}}\right)\right]$ OTf ([4]OTf): A solution of 4,4,4-trifluoro-1-phenyl-1,3-butanedione (126 mg, $0.584 \mathrm{mmol}$ ) and $\mathrm{NaOCH}_{3}(32 \mathrm{mg}, 0.59 \mathrm{mmol}$ ) in THF was stirred for $30 \mathrm{~min}$, after which the solvent was removed under vacuum to give white $\mathrm{Na}\left(\mathrm{acac}^{\mathrm{PhF}}\right)$. $\mathrm{Na}\left(\mathrm{acac}^{\mathrm{PhF}}\right)$ was then dissolved in $\mathrm{CH}_{3} \mathrm{CN}(5$ $\mathrm{mL}$ ) and slowly added to a solution of [1] $(\mathrm{OTf})_{2}(704 \mathrm{mg}, 0.583 \mathrm{mmol})$ in $\mathrm{CH}_{2} \mathrm{Cl}_{2}(5 \mathrm{~mL})$. The purple solution was stirred overnight and the solvent was removed under vacuum. The residue was dissolved in $\mathrm{CH}_{2} \mathrm{Cl}_{2}(5 \mathrm{~mL})$, filtered, and layered with pentane to yield deep red crystals suitable for X-ray crystallography $\left(457 \mathrm{mg}\right.$ ); yield $68 \%$. The X-ray structure revealed uncoordinated $\mathrm{CH}_{2} \mathrm{Cl}_{2}$ molecules in the asymmetric units, and elemental analysis suggests that a small amount of solvent ( $\approx 0.7$ equiv.) remains after vacuum drying. $\mathrm{C}_{59} \mathrm{H}_{45} \mathrm{~F}_{6} \mathrm{FeN}_{6} \mathrm{O}_{5} \mathrm{PS} \cdot 0.7 \mathrm{CH}_{2} \mathrm{Cl}_{2}$ (1210.36): calcd. C 59.24, H 3.86, N 6.94; found C 59.25, H 3.99, N 6.75. UV/Vis (MeCN): $\lambda_{\max }\left(\epsilon, \mathrm{M}^{-1} \mathrm{~cm}^{-1}\right)=519$ (720), 494 (730) nm. IR (neat): $\tilde{v}=3058,2955,1602[\mathrm{v}(\mathrm{C}=0)], 1572,1462,1443,1253,1141,1029,981 \mathrm{~cm}^{-1} .{ }^{19} \mathrm{~F} \mathrm{NMR}(376$ $\mathrm{MHz}, \mathrm{CD}_{2} \mathrm{Cl}_{2}$ ): $\delta=-44.9\left(\mathrm{acac}^{\mathrm{PhF}}\right),-77.7$ (OTf) ppm.

[Fe(4-TIP $\left.\left.{ }^{\mathrm{Ph}}\right)(\mathrm{OAc})(\mathrm{MeOH})\right]_{\mathrm{BPh}}$ ([5]BPh 4$): \mathrm{Fe}(\mathrm{OAc})_{2}(488 \mathrm{mg}, 2.81 \mathrm{mmol})$ and 4-TIPPh $(1.28 \mathrm{~g}, 2.79$ $\mathrm{mmol}$ ) were stirred in $\mathrm{MeOH}(10 \mathrm{~mL})$ for $10 \mathrm{~min}$ while the solution became clear. A solution of $\mathrm{NaBPh}_{4}(956 \mathrm{mg}, 2.79 \mathrm{mmol}$ ) in $\mathrm{MeOH}$ was then added dropwise and the mixture was stirred for $5 \mathrm{~h}$. During this time, a white precipitate developed. The white solid was collected and recrystallized from $\mathrm{MeOH}$ at $-30{ }^{\circ} \mathrm{C}$; yield $48 \%$. Elemental analysis indicates that the bound $\mathrm{MeOH}$ ligand only partially (50\%) occupied the complex in the ground, vacuum-dried solid. $\mathrm{C}_{53} \mathrm{H}_{44} \mathrm{BFeN}_{6} \mathrm{O}_{2} \mathrm{P} \cdot 0.5 \mathrm{MeOH}(910.6)$ : calcd. C 70.57, H 4.98, N 9.23; found C 70.69, H 5.08, N 8.95. IR (neat): $\tilde{V}=3304,3259$ [v(N-H)], 3054, 2999, 2993, 2928, 1562 [ $\left.\mathrm{V}_{\mathrm{as}}(\mathrm{OCO})\right], 1478,1402\left[\mathrm{v}_{\mathrm{s}}(\right.$ OCO $\left.)\right], 1341 \mathrm{~cm}^{-1}$.

[Fe(4-TIP $)(s a l)](6):$ A suspension of [5]BPh $4(142 \mathrm{mg}, 0.159 \mathrm{mmol})$ and sodium salicylate $(28.0 \mathrm{mg}$, $0.175 \mathrm{mmol}$ ) was stirred overnight in $\mathrm{MeOH}(5 \mathrm{~mL})$. The resulting yellow solution was layered with MeCN to provide X-ray-quality crystals of 6; yield $32 \% . \mathrm{C}_{34} \mathrm{H}_{25} \mathrm{FeN}_{6} \mathrm{O}_{3} \mathrm{P}$ (652.4): calcd. C 62.59, $\mathrm{H} 3.86, \mathrm{~N}$ 12.88; found C 62.19, H 3.98, N 12.52. UV/Vis (MeOH): $\lambda_{\max }\left(\epsilon, \mathrm{M}^{-1} \mathrm{~cm}^{-1}\right)=440$ (150) nm. IR (neat): $\tilde{v}=$ $3133,3052,2900,1598,1563,1521,1476,1458,1439,1386,1314 \mathrm{~cm}^{-1}$.

X-ray Structure Determination: XRD data were collected at $100 \mathrm{~K}$ with an Oxford Diffraction SuperNova kappa-diffractometer (Agilent Technologies) equipped with dual microfocus Cu/Mo X-ray sources, X-ray mirror optics, Atlas CCD detector, and low-temperature Cryojet device. Crystallographic data for particular compounds are summarized in Table $\underline{4}$. The data were analyzed with the CrysAlis Pro program package (Agilent Technologies, 2011) typically using a numerical Gaussian absorption correction (based on the real shape of the crystal), followed by an empirical multiscan correction using the SCALE3 ABSPACK routine. The structures were solved using the SHELXS program and refined with the SHELXL program 29 within the Olex2 crystallographic package. $\underline{30} \mathrm{~B}-, \mathrm{H}-$, and C-bonded hydrogen atoms were positioned geometrically and refined using appropriate geometric restrictions on the corresponding bond lengths and bond angles within a riding/rotating model (torsion angles of methyl hydrogen atoms were rotationally optimized to better fit the residual electron density). The positions of the methanolic hydrogen atoms $(\mathrm{H} 3)$ in [2] OTf.4MeOH and [5] $\mathrm{BPh}_{4} \cdot 3 \mathrm{MeOH}$ were refined freely. The remaining $\mathrm{OH}$ groups were refined using geometrical restrictions and rotationally optimized to better fit the residual electron density. Crystals of [4]OTf. $2 \mathrm{CH}_{2} \mathrm{Cl}_{2}$ represent pseudo-orthorhombic quasi- 
merihedral twins $\left(B \approx 90^{\circ}\right)$. Crystals of $[5] \mathrm{BPh}_{4} \cdot 3 \mathrm{MeOH}$ are systematic twins grown together along a common bc plane. The chiral space group $\left(P 2_{1}\right)$ of [5] $\mathrm{BPh}_{4} \cdot 3 \mathrm{MeOH}$ does not result from the molecular chirality of the cation, but rather from crystal packing. The cation itself has an approximate local mirror symmetry (in the direction perpendicular to crystallographic $z$ axis). The apparent result of this local symmetry is the observed twinning. The twinning, however, annihilates the chirality on the macroscopic level since the components of the twin are of opposite chirality.

Table 4. Summary of the X-ray crystallographic data collection and structure refinement.

\begin{tabular}{|c|c|c|c|c|c|}
\hline & $\begin{array}{l}{[1](0 T f)_{2} \cdot 0.5 E t} \\
{ }_{2} \mathrm{O}\end{array}$ & $\begin{array}{l}\text { [2]OTf·4MeO } \\
\mathrm{H}\end{array}$ & $\begin{array}{l}{[4] \mathrm{OTf} \cdot 2 \mathrm{CH}_{2} \mathrm{Cl}_{2}} \\
\text { [a] }\end{array}$ & $\begin{array}{l}{[5] \mathrm{BPh}_{4} \cdot 3 \mathrm{M}} \\
\mathrm{eOH}\end{array}$ & $\begin{array}{l}\text { 6.MeCN.M } \\
\text { eOH }\end{array}$ \\
\hline Empirical formula & $\begin{array}{l}\mathrm{C}_{58} \mathrm{H}_{53} \mathrm{~F}_{6} \mathrm{FeN}_{9} \mathrm{O} \\
6.5 \mathrm{PS}_{2}\end{array}$ & $\begin{array}{l}\mathrm{C}_{61} \mathrm{H}_{64} \mathrm{~F}_{3} \mathrm{FeN}_{6} \\
\mathrm{O}_{10} \mathrm{PS}\end{array}$ & $\begin{array}{l}\mathrm{C}_{61} \mathrm{H}_{49} \mathrm{Cl}_{4} \mathrm{~F}_{6} \mathrm{FeN} \\
{ }_{6} \mathrm{O}_{5} \mathrm{PS}\end{array}$ & $\begin{array}{l}\mathrm{C}_{57} \mathrm{H}_{60} \mathrm{BFeN}_{6} \\
\mathrm{O}_{6} \mathrm{P}\end{array}$ & $\begin{array}{l}\mathrm{C}_{37} \mathrm{H}_{32} \mathrm{FeN}_{7} \\
\mathrm{O}_{4} \mathrm{P}\end{array}$ \\
\hline Formula weight & 1245.03 & 1217.06 & 1320.77 & 1022.74 & 725.52 \\
\hline Crystal system & triclinic & triclinic & monoclinic & monoclinic & monoclinic \\
\hline Space group & $P \bar{I}$ & $P \overline{\mathrm{I}}$ & $P c$ & $P 2_{1}$ & $P 2_{1} / n$ \\
\hline$a[\AA]$ & $13.3432(3)$ & $14.9470(5)$ & $16.0689(5)$ & $13.8829(3)$ & $13.6187(7)$ \\
\hline$b[\AA]$ & $15.8007(3)$ & $15.1921(5)$ & $20.6668(5)$ & $11.6385(4)$ & 14.9164(9) \\
\hline$c[\AA]$ & $27.8621(6)$ & $16.4349(6)$ & $19.6239(4)$ & $16.5130(4)$ & $17.5278(8)$ \\
\hline$\alpha\left[^{\circ}\right]$ & $76.994(2)$ & $90.642(3)$ & 90 & 90 & 90 \\
\hline $8\left[^{\circ}\right]$ & $88.757(2)$ & $113.784(3)$ & $90.088(2)$ & $91.591(2)$ & $102.190(5)$ \\
\hline$V\left[^{\circ}\right]$ & $87.690(2)$ & $115.873(4)$ & 90 & 90 & 90 \\
\hline$V\left[\AA^{3}\right]$ & $5718.4(2)$ & 2992.3(3) & 6516.9 & $2667.1(2)$ & $3480.4(3)$ \\
\hline$Z$ & 4 & 2 & 4 & 2 & 4 \\
\hline$D_{\text {calcd. }\left[\mathrm{g} \mathrm{cm}^{3}\right]}$ & 1.446 & 1.351 & 1.325 & 1.274 & 1.385 \\
\hline$\lambda[\AA]$ & 1.5418 & 1.5418 & 0.7107 & 1.5418 & 1.5418 \\
\hline$\mu\left[\mathrm{mm}^{-1}\right]$ & 3.749 & 3.205 & 0.489 & 2.996 & 4.328 \\
\hline$\vartheta$ range $\left[{ }^{\circ}\right]$ & 7 to 149 & 7 to 148 & 7 to 59 & 4 to 148 & 4 to 149 \\
\hline Reflections collected & 64740 & 39217 & 56565 & 32914 & 26690 \\
\hline \multirow{2}{*}{$\begin{array}{l}\text { Independent } \\
\text { reflections }\end{array}$} & 22662 & 11891 & 28249 & 10151 & 6954 \\
\hline & $\left(R_{\mathrm{int}}=0.0315\right)$ & $\left(R_{\text {int }}=0.0299\right)$ & $\left(R_{\text {int }}=0.0339\right)$ & $\begin{array}{l}\left(R_{\text {int }}=\right. \\
0.1419)\end{array}$ & $\begin{array}{l}\left(R_{\mathrm{int}}=\right. \\
0.0278)\end{array}$ \\
\hline $\begin{array}{l}\text { Data/restraints/para } \\
\text { meters }\end{array}$ & $\begin{array}{l}22662 / 19 / 159 \\
1\end{array}$ & $11891 / 2 / 784$ & $\begin{array}{l}28249 / 12 / 155 \\
0\end{array}$ & $\begin{array}{l}10151 / 87 / 6 \\
43\end{array}$ & $\begin{array}{l}6954 / 0 / 45 \\
4 \\
\end{array}$ \\
\hline GOF (on $F^{2}$ ) & 1.025 & 1.028 & 1.061 & 1.025 & 1.037 \\
\hline$R 1 / w R 2[I>2 \sigma(I)][\mathrm{b}]$ & $0.0332 / 0.0855$ & $\begin{array}{l}0.0413 / 0.109 \\
4\end{array}$ & $0.0608 / 0.1541$ & $\begin{array}{l}0.0682 / 0.17 \\
78\end{array}$ & $\begin{array}{l}0.0273 / 0.0 \\
710\end{array}$ \\
\hline$R 1 / w R 2$ (all data) & $0.0374 / 0.0886$ & $\begin{array}{l}0.0449 / 0.112 \\
8\end{array}$ & $0.0666 / 0.1613$ & $\begin{array}{l}0.0872 / 0.19 \\
63\end{array}$ & $\begin{array}{l}0.0306 / 0.0 \\
731\end{array}$ \\
\hline
\end{tabular}

[a] One of the solvates in [4]OTf $2 \mathrm{CH}_{2} \mathrm{Cl}_{2}$ is partially occupied by a pentane molecule.

[b] $R 1=\Sigma|| F_{\mathrm{o}}|-| F_{\mathrm{c}}|| / \Sigma\left|F_{\mathrm{o}}\right| ; w R 2=\left[\Sigma w\left(F_{\mathrm{o}}^{2}-F_{\mathrm{c}}^{2}\right)^{2} / \Sigma w\left(F_{\mathrm{o}}^{2}\right)^{2}\right]^{1 / 2}$.

\section{Acknowledgements}

This research was supported by the National Science Foundation (NSF) (CAREER CHE-1056845) and Marquette University. 


\section{References}

1 1a M. Costas, M. P. Mehn, M. P. Jensen, L. Que Jr, Chem. Rev. 2004 , 104, 939 - 986. 1b E. I.

Solomon, T. C. Brunold, M. I. Davis , J. N. Kemsley, S.-K. Lee, N. Lehnert, F. Neese , A. J. Skulan, Y.-S. Yang , J. Zhou , Chem. Rev. 2000 , 100 , 235 - 349. 1c D. T. Gibson, R. E. Parales, Curr. Opin.

Biotechnol. $2000,11,236-243$.

2 2a T. D. H. Bugg, Curr. Opin. Chem. Biol. 2001 , 5 , 550 - 555. 2b T. D. H. Bugg, G. Lin , Chem. Commun. 2001 , 11 , $941-953.2 c$ E. G. Kovaleva , J. D. Lipscomb , Nature Chem. Biol. 2008 , 4 , $186-193$.

3 3a B. Kauppi , K. Lee , E. Carredano , R. E. Parales, D. T. Gibson , H. Eklund, S. Ramaswamy , Structure 1998, 6 , 571 - 586. 3b A. Karlsson , J. V. Parales, R. E. Parales , D. T. Gibson , H. Eklund, S. Ramaswamy , Science 2003 , 299 , 1039-1042.

4 4a G. P. Titus, H. A. Mueller, J. Burgner, S. R. d. Córdoba, M. A. Penalva, D. E. Timm, Nat. Struct. Biol. 2000 , 7 , 542 - 546. 4b F. H. Vaillancourt , J. T. Bolin , L. D. Eltis , Crit. Rev. Biochem. Mol. Biol. $2006,41,241-267$.

5 5a T. E. Machonkin , A. E. Doerner , Biochemistry 2011 , 50 , 8899 - 8913. 5b T. E. Machonkin , P. L. Holland, K. N. Smith, J. S. Liberman , A. Dinescu, T. R. Cundari, S. S. Rocks , J. Biol. Inorg. Chem. 2010 , 15 , 291 - 301. 5c Y. Yin , N. Y. Zhou , Curr. Microbiol. 2010 , 61 , 471-476. 5d L. Y. Xun , J. Bohuslavek, M. A. Cai , Biochem. Biophys. Res. Commun. 1999, 266 , $322-325$.

6 6a K. D. Koehntop , J. P. Emerson, L. Que Jr , J. Biol. Inorg. Chem. 2005 , 10 , 87-93. 6b Arianna Bassan, Tomasz Borowski, P. E. M. Siegbahn , Dalton Trans. 2004 , $1353-1362$.

7 7a G. D. Straganz , B. Nidetzky , ChemBioChem 2006 , 7 , 1536-1548. 7b S. Leitgeb , B. Nidetzky, Biochem. Soc. Trans. 2008, 36, 1180-1186.

8 8a C. R. Simmons, Q. Liu , Q. Huang, Q. Hao , T. P. Begley, P. A. Karplus, M. H. Stipanuk , J. Biol. Chem. 2006 , 281 , 18723-18733. 8b C. A. Joseph, M. J. Maroney , Chem. Commun. $2007,3338-3349$.

9 9a G. Straganz, L. Brecker , H. J. Weber, W. Steiner, D. W. Ribbons, Biochem. Biophys. Res. Commun. 2002 , 297 , 232 - 236. 9b G. D. Straganz , A. Glieder , L. Brecker , D. W. Ribbons , W. Steiner , Biochem. J. $2003,369,573-581$.

10 10a J. Chen, W. Li , M. Z. Wang , G. Y. Zhu , D. Q. Liu , F. Sun, N. Hao , X. M. Li , Z. H. Rao , X. C. Zhang , Protein Sci. 2008 , 17, 1362 - 1373. 10b M. R. Harpel , J. D. Lipscomb , J. Biol. Chem. $1990,265,22187-22196$.

11 11a I. Matera, M. Ferraroni , S. Burger , A. Scozzafava , A. Stolz , F. Briganti , J. Mol. Biol. 2008 , 380 , 856 - 868. 11b J. P. Hintner , T. Remtsma , A. Stolz , J. Biol. Chem. 2004 , 279 , 37250 - 37260. 11c J. P. Hintner , C. Lechner , U. Riegert , A. E. Kuhm , T. Storm , T. Reemtsma , A. Stolz , J. Bacteriol. 2001 , 183, 6936-6942.

12 P. C. A. Bruijnincx , G. van Koten , R. J. M. K. Gebbink, Chem. Soc. Rev. 2008 , 37 , $2716-2744$. 13 13a N. Kitajima , N. Tamura , H. Amagai , H. Fukui , Y. Moro-oka , Y. Mizutani , T. Kitagawa, R. Mathur, K. Heerwegh , C. A. Reed, C. R. Randall , L. Que Jr, K. Tatsumi , J. Am. Chem. Soc. 1994 , 116 , 9071 - 9085. 13b E. H. Ha , R. Y. N. Ho , J. F. Kesiel , J. S. Valentine, Inorg. Chem. 1995 , 34 , 2265 - 2266. 13c M. P. Mehn , K. Fujisawa , E. L. Hegg , L. Que Jr , J. Am. Chem. Soc. 2003 , 125, 7828 - 7842. 13d A. Mukherjee, M. A. Cranswick, M. Chakrabarti , T. K. Paine , K. Fujisawa, E. Munck, L. Que , Inorg. Chem. 2010 , 49 , 3618 - 3628. 13e T. Ogihara , S. Hikichi , M. Akita , Y. Moro-oka , Inorg. Chem. 1998, 37, $2614-2615$.

14 14a N. Burzlaff, in Advances in Inorganic Chemistry, Vol. 60 (Ed.: R. van Eldik ), 2008 , pp. 101-165. 14b A. Beck , B. Weibert, N. I. Burzlaff , Eur. J. Inorg. Chem. 2001, 521 - 527. 14c A. Beck , A. Barth , E. Hulbner , N. Burzlaff , Inorg. Chem. 2003 , 42 , $7182-7188$. 
15 P. C. A. Bruijnincx , M. Lutz , A. L. Spek, W. R. Hagen , B. M. Weckhuysen, G. van Koten , R. J. M. K. Gebbink, J. Am. Chem. Soc. 2007, 129 , 2275- 2286.

16 16a R. S. Brown, J. Huguet, Can. J. Chem. 1980 , 58, $889-901.16$ b R. Breslow , J. T. Hunt , R. Smiley, T. Tarnowski , J. Am. Chem. Soc. 1983 , 105, 5337 - 5342. 16c H. Slebocka-Tilk , J. L. Cocho , Z. Frakman , R. S. Brown , J. Am. Chem. Soc. 1984 , 106 , 2421 - 2431. 16d W. E. Allen , T. N. Sorrell , Inorg. Chem. 1997 , 36, 1732 - 1734. 16e C. Kimblin , W. E. Allen , G. Parkin , J. Chem. Soc., Chem. Commun. 1995 , 1813 - 1815. 16f W. E. Lynch, J. D. M. Kurtz, S. Wang , R. A. Scott , J. Am. Chem. Soc. 1994 , 116, 11030-11038. 16g P. C. Kunz , G. J. Reiss , W. Frank, W. Klaui, Eur. J. Inorg. Chem. 2003 , 3945 - 3951. 16h P. C. Kunz, W. Klaui , Collect. Czech. Chem. Commun. $2007,72,492-502$.

17 17a A. Y. S. Malkhasian, B. Nikolovski, B. E. Kucera, R. Loloee, F. A. Chavez, Z. Anorg. Allg. Chem. 2007 , 633 , 1000 - 1005. 17b M. P. Batten , A. J. Canty , K. J. Cavell , T. Ruther , B. W. Skelton, A. H. White , Acta Crystallogr., Sect. C 2004, 60 , M311-M313. 17c F.-J. Wu , D. M. Kurtz Jr , J. Am. Chem. Soc. $1989,111,6563-6572$.

18 18a F. J. Wu , D. M. Kurtz , K. S. Hagen, P. D. Nyman , P. G. Debrunner , V. A. Vankai , Inorg. Chem. 1990 , 29 , 5174-5183. 18b V. A. Vankai , M. G. Newton , D. Kurtz Jr , Inorg. Chem. $1992,31,342-343$.

19 H. Park, J. S. Baus, S. V. Lindeman , A. T. Fiedler , Inorg. Chem. 2011 , 50, $11978-11989$.

20 20a G. D. Straganz , A. R. Diebold, S. Egger , B. Nidetzky , E. I. Solomon , Biochemistry 2010 , 49 , $996-1004$. 20b S. Leitgeb , G. D. Straganz , B. Nidetzky, Biochem. J. 2009 , 418, 403-411.

21 P. G. Edwards , A. Harrison, P. D. Newman , W. J. Zhang , Inorg. Chim. Acta 2006 , 359 , $3549-3556$.

22 L. H. Gade, G. Marconi , C. Dro , B. D. Ward , M. Poyatos, S. Bellemin-Laponnaz , H. Wadepohl , L. Sorace, G. Poneti , Chem. Eur. J. 2007 , 13 , $3058-3075$.

23 A. W. Addison, T. N. Rao , J. Reedijk, J. Vanrijn, G. C. Verschoor , J. Chem. Soc., Dalton Trans. $1984,1349-1356$.

24 K. Fujisawa, N. Tada , Y. Nishida, Y. Miyashita, K. Okamoto, Inorg. Chem. Commun. $2008,11,381-384$.

25 25a G. D. Straganz , H. Hofer, W. Steiner, B. Nidetzky , J. Am. Chem. Soc. 2004 , $126,12202-12203.25 b$ G. D. Straganz , B. Nidetzky , J. Am. Chem. Soc. $2005,127,12306-12314$.

26 Ferric salicylate complexes have been reported in the following papers, see:

26a M. R. McDevitt , A. W. Addison , E. Sinn , L. K. Thompson , Inorg. Chem. 1990 , 29 , 3425 - 3433. 26b N. Y. Oh, M. S. Seo , M. H. Lim , M. B. Consugar, M. J. Park , J.-U. Rohde , J. Han , K. M. Kim , J. Kim , L. Que Jr , W. Nam , Chem. Commun. 2005 , 5644-5646. 26c S. Taktak, M. Flook , B. M. Foxman, L. Que Jr , E. V. Rybak-Akimova, Chem. Commun. 2005 , $5301-5303$. 26d O. V. Makhlynets, P. Das, S. Taktak, M. Flook, R. Mas-Balleste, E. V. Rybak-Akimova , L. Que, Chem. Eur. J. 2009 , 15, 13171-13180.

27 27a S. L. Groce , J. D. Lipscomb , Biochemistry 2005 , 44 , $7175-7188$. 27b J. D. Lipscomb , Curr. Opin. Struct. Biol. $2008,18,644-649$.

28 F. J. LaRonde, M. A. Brook, Inorg. Chim. Acta 1999 , 296 , $208-221$.

29 G. M. Sheldrick , Acta Crystallogr., Sect. A 2008, 64, $112-122$.

30 O. V. Dolomanov, L. J. Bourhis, R. J. Gildea , J. A. K. Howard, H. Puschmann , J. Appl. Crystallogr. $2009,42,339-341$. 